\title{
Prince, Pen, and Sword: Eurasian Perspectives
}

\author{
Jeroen Duindam
}

1

\section{Global History}

This book on the relationship between rulers and elites in Eurasian polities started out as an attempt to bridge the gap between two contradictory but equally valid impulses. All history is regional history: scholars need languages and contexts to make sense of the past. At the same time, regional compartmentalization turns history into a dead-end street: only more comprehensive views can show the specificity of regions as well as their multiple connections. The authors were trained as regional specialists, and have worked with primary sources in the languages and scripts connected to their areas of expertise. Yet at the same time, they noticed the limitations of the area perspective, and subscribe, in one way or another, to the current challenge to move towards a more global understanding of history.

We share these conflicting loyalties with many other scholars, and over the last four decades several paradigms took shape to deal with the challenge of combining specialized research with the global horizon. The introduction considered some of these paradigms and outlined our preliminary choices. Comparison, whether regional or global, defines themes and questions that are equally relevant in different settings and examines the variety in outcomes with the intention to make sense of divergences. It takes diversity for granted but looks for patterns in human behaviour. One of the main challenges facing comparative historians is to define questions that do not accept as standard the specific experiences of one region or period; this problem is relevant for all historians, but it becomes painfully explicit in the case of comparatists. Secondly, it is particularly difficult for comparative historians to acquire an equal basis of knowledge and materials for all areas they include: extension of scope will necessarily reduce depth of the comparison. There is a third complication: the availability and the nature of source materials vary greatly from region to region. The problem, therefore, is more fundamental than the researchers' ability to master languages or find enough time to read materials. With a specific theme and carefully crafted set of questions, however, global comparison can be a powerful intellectual tool and a necessary safeguard against cultural parochialism. 
We deal in different ways with these challenges. Jeroen Duindam's chapter on the court explicitly combines Eurasian and global levels of comparison. The critical assessment of some more widely accepted Eurasian divergences and the subsequent elaboration of several globally shared functions move his comparison beyond the level of describing 'differences and similarities'. Peter Rietbergen, Maaike van Berkel, and Richard van Leeuwen stay within the bounds of Eurasia, considering each of the three macro-regions with equal attention. Jos Gommans's interpretation of the Central Eurasian warband moves closer to connected history: he concentrates on the Inner Asian core lands and traces the emulations of the Chinggisid warband in contiguous post-nomadic empires. Liesbeth Geevers and Marie Favereau deal with the Habsburgs and Jochids respectively in their jointly written comparative chapter. All chapters approach political questions with a cultural perspective akin to the priorities of connected history and zoom in on the perceptions of contemporaries. Two contributors, in particular, focus on literary sources that can be found in all regions discussed: Richard van Leeuwen on fiction and Maaike van Berkel on advice literature. Their comparison raises a question relevant for all chapters-and to some extent for all historical scholarship: the ambiguous relationship between the representations written by contemporaries and the social realities of the worlds they lived in, as far as we can hope to reconstruct these on the basis of various sources. Comparison, we argue, needs to take into account both levels as well as their at times puzzling interaction.

The connected perspective has corrected narrow views of European expansion as a one-way process; it has also counteracted the tendency to compartmentalise the globe in rigid cultural zones. Within each of the macro-regions defined as the basis of our project, a lingua franca and a shared moral-religious background facilitated understanding. Between contiguous regions long traditions of contact eased communication. West Asia and Europe shared legacies and examples, and the same can be said to some extent about the contiguous zones of Central and East Asia. The repeated movement of Central Asian peoples in all directions, too, created a basis for further contact. Europeans moving to East Asia, however, relied on a relatively thin stream of previous information, and contacts here left even more room for protracted misunderstandings as well as for manipulation by intermediaries than the contact between Europe and West Asia. ${ }^{1}$ The overarching view of the comparatist or the generalist needs

1 This was one of the conclusions of a conference organized by Christian Windler and Henrietta Harrison at the University of Bern (2-4 June 2016): 'Transformations of Intercultural Diplomacies: Comparative Views on Asia and Europe (1700 to 1850)'. The presence of drago- 
to build on the careful analysis of contacts and contact zones as well as the interpretation of sources generated by people moving around the globe. Comparatists may be able to outline broad and fundamental cultural differencesyet they should by now have accepted the notion that no sharp boundaries exist between cultures and that reciprocal contacts create all sorts of intermediate forms.

For the authors, the experience of writing this book made clear that global history remains unfinished business. Global history can subsist neither on the accumulated detailed description of encounters and travellers, nor on the energetic generalist emphasis on Big Data and Big Questions. Specialists dealing with the political heart of any empire will acknowledge the remarkable impact of personalities, political contingency, and cultural contexts; generalists examining the connections between rulers and elites will recognise patterns that recur in many places. In the gradually emerging mosaic of global history we have sought a middle ground, integrating a huge great variety of specialised literature and, wherever possible, primary sources—-mostly published, partly in translation. A more lasting and balanced form of global history can arise only if the middle ground proposed here can take shape at the institutional level, bringing together on a daily basis students and staff studying many parts of the globe.

The partnership between prince, pen and sword was a precondition for political stability; conversely, elite discord could lead to rebellion. Traditional political thought viewed history in terms of cycles, and its observations contain more than a grain of truth. No empire or kingdom escaped from political breakdown; no single line of rulers persisted indefinitely, and elites were frequently reshuffled.

Notwithstanding the turmoil, however, lasting images of continuity developed. Imperial China was repeatedly torn apart by rebellion and conquest, yet the notion of a single coherent Chinese polity, based on a number of culturalpolitical axioms, persisted. ${ }^{2}$ Nomadic polities on the Central Asian Steppe

mans and other groups of intermediaries was an important theme here. Henrietta Harrison pointed to the remarkable freedoms taken in the negotiations by the Chinese Christian interpreter Jacob Ly, member of the 1793 Macartney mission to Qianlong.

2 See Yuri Pines, The Everlasting Empire: The Political Culture of Ancient China and Its Imperial Legacy (Princeton, 2012). 
were known for their multiple breakups as well as for repeated waves of conquest, yet the example of great leaders and their warbands stretched far beyond these heartlands and retained a powerful appeal centuries after their demise. The Ottomans, a remarkably long-lasting dynasty surviving several profound crises, propped up their supreme authority by integrating earlier Islamic and Byzantine traditions into their outlook. Amidst endless rebellions and wars, European kingdoms obtained a flexible set of traditions pertaining to religion, the ruling house, and the people. Regimes and dynasties changed: times of troubles can be found in the annals of every single polity. Yet all polities cultivated persisting images and traditions that were invariably revived once order was re-established, often under a new dynasty. ${ }^{3}$

The rise to power of new leaders entailed the reconfiguration of elites as well as a process of cultural re-invention of the dynasty. Conquerors and usurpers glorified the rise of their own house, but needed to appropriate moral-religious authority and the dynastic prestige of their predecessors. The chapters of this book, and the dissertations of researchers involved in our project, all focus on elements of this repeating process. ${ }^{4}$ The mixed and contingent character of dynastic appropriations strikes the eye, as does the manifest relevance of shared worldviews

\section{$3 \quad$ Shared Worldviews}

The grandest and most lasting of the traditions underpinning rule were tied to a higher moral order, which provided a divine sanction as well as a sense of continuity with ancestors and future generations. We find no examples of premodern rulers who failed to seek the endorsement of celestial powers. They did

3 Norman Davies, Vanished Kingdoms: The History of Half-Forgotten Europe (London, 2012), rightly points out that many polities were absorbed by their more successful neighboursthese vanished kingdoms tend to be left aside by historians, concentrating on success more often than on failure.

4 Willem Flinterman, 'The Cult of Qalāwūn: Waqf, Memoria, and Dynasty in the Early Mamluk Sultanate, ca. 1280-1340'; Lennart Bes, 'Imperial Servants on Local Thrones. Dynastic Politics in the Vijayanagara Successor States'; Hans Voeten, 'The Kolyvan-Voskresensk Plants and the Russian Integration of Southern Siberia, $1725^{-1783^{\prime}}$ deal with different elements of this process; the same can be said for Cumhur Bekar's discussion of the rise of the Köprülü viziers. Kim Ragetli focuses on Burgundian duchesses as intermediaries between the duke and cities; Barend Noordam on the convergence of martial and literati ideals in the work of the late Ming general Qi Jiguang. 
not stand alone in their reflex. Rietbergen states that 'the belief of the majority of people that a ruler's virtue would somehow influence (the) god(s) to bring them safety and prosperity was indeed a prime basis of authority and power. ${ }^{5}$ A magical-religious worldview permeated the lives of rulers and subjects alike. Harmony, hierarchy, and order were understood as the terrestrial expression of celestial values. This was no mere pragmatic alliance of throne and altar: the moral dictate engendered major responsibilities for all. Subjects were required to obey and conform to moral requirements; yet princes were expected to safeguard harmonies and protect the weaker among their subjects. While such expectations did not usually work out in practice, the standard was always there, for kings and advisors, as well as for the people at large. Introspective kings may have been more impressed than men of action, yet all rulers expected a day of reckoning: they knew they would be judged by divine powers and by posterity.

The powerful ideal of the righteous king could be held up by advisors as a mirror to rulers, especially to those who failed to meet even modest standards. The intermittent appearance of archetypally bad kings, in stories as well as in political reality, served as a warning for all that the system was hardly foolproof. Contestants for the throne were always available, yet only rarely was there a visible and viable alternative for the principle of dynastic rule. Richard van Leeuwen's chapter in this book underlines the ubiquity of kings in fiction, as well as the 'composite' nature of kingship, as a discourse with advisors, women, and to some extent the populace. Compliance was first and foremost the consequence of a worldview shared by all social groups, a classic case of Weber's definition of Herrschaft: obeying out of overall support for the constellation of ideas. ${ }^{6}$

Secular and religious powers were rarely united harmoniously in a single hand. The balance between these two powers varied regionally and over time. Remarkably, the most enduring lines of rulers appear to have been those whose status was defined primarily in religious and moral terms. Exemplars with little or no political power did not need to sully their hands and could subsist aloof but untarnished in the minds of their peoples. The Japanese imperial line may be the strongest example of this tendency: retired emperors, regents, or shoguns dealt with government matters, while the emperors developed into a distant, untouchable, but powerful symbol. In East Asia, rulers more often

5 See Rietbergen, chapter 3 in this volume, 293.

6 Max Weber, Wirtschaft und Gesellschaft: Grundriss der verstehenden Soziologie (Tübingen, 1972) 28-29, expressed as 'ideal normative agreement' in David Held, 'Power and Legitimacy', Political Theory and the Modern State (Cambridge 1989) 99-157, note at 101-102. 
appear as distant moral exemplars; elsewhere visibility, active government, and martial prowess ranked higher among the requirements of kingship. These ideals, and the need to be just and accessible, were often stressed in European and West and South Asian advice literature. However, no easy geographical typology of power can be suggested: tendencies were often contradicted by the personal inclinations of individuals on the throne. Nor is it plausible to picture royalty across Eurasia as gradually withdrawing from the public over time. Striking examples of easy camaraderie, or, conversely, of stifling decorum and isolation, can be found in many places and times.

It is clear, however, that the rites of rulership were more commonly performed in relative isolation in East Asia, whereas in other parts of Asia as well as in Europe, variable audiences would be admitted to these events. This divergence can be explained by the categorical status of Chinese as well as Japanese emperors as moral exemplars and as guardians of cosmic harmonies. They could not risk being blemished by day-to-day political wrangling; neither was a role as active leader and commander of armies best suited to safeguard their realm. The nature of the Chinese grand sacrifices, the secluded setting of the emperor in the palace, and the rules against depicting the emperor or using certain characters or items related to his name bring to mind some of the taboos surrounding African ritual kings. They, too, stood at the pinnacle of the world, as the intermediary between the dead and the living, the celestial and the terrestrial. For African ritual kings and Chinese emperors alike, the ritual attached to their elevated position severely circumscribed the freedom of the incumbent. This general characteristic was undoubtedly stronger in Africa and East Asia than in West-South Asia and Europe.

Rites of royalty immediately bring to mind another aspect of religious performance: its capacity to dazzle and inspire multitudes. Whether they were performed in public or in secluded settings, in palaces, temples, market squares, or in an open field, few royal rituals were wholly void of religious artefacts, practices, and associations. Surely rulers instrumentally used this potential to inspire and impress: they were well aware of the impact a good show could have. Yet there is no reason to take this as evidence of a distanced and 'merely' instrumental approach to their exalted station. Instrumental use of ritual appurtenances did not necessarily clash with devout adherence to the key moralreligious principles of rulership. The choreography of royal ceremonies was a matter of grave concern for most princes, whether or not such events were to be witnessed by cheering crowds. Distinguishing the secluded setting of Japanese or Chinese imperial sacrifices from the more accessible ceremonies of West and South Asia or Europe should not lead us to assume that the absence or presence of spectators wholly defined the motives of the prince. Concealment 
did not exclude instrumental attitudes; neither does the presence of audiences tell us much about the mindset of the main ritual performers. ${ }^{7}$

Rulers sought to harness religious leadership and at times aspired to combine secular and religious supremacy. In addition, they were eager to obtain the numerous advantages generated by religious institutions. Indubitably, there was also a strong instrumental impulse at work here. Rulers sought to control religious establishments by acquiring rights of patronage and by reaping the economic benefits generated by religion. The religious mandate could be used to impose orthodoxy, stifle heterodoxy, and throttle rebellion. Conversely, however, social and political rebellions were often inspired by religion. The moral programme of religion worked both ways: it underlined order and obedience, but also presented a catalogue of virtues that could be held up to the king. Elites of the pen and the book would constantly remind the prince of these virtues, and they were usually responsible for educating dynastic scions. The righteous and just treatment of the people ranked high among royal virtues: blatant disregard of this prime requirement could take away the Mandate of Heaven and thus open the gates to popular rebellion. This principle was perceived not only by learned elites: popular fiction would depict the inescapable fate of evil rulers. Overall, the moral-religious code permeating all aspects of life underlined hierarchy and obedience: the punishment of evil princes was the responsibility of divine powers. Yet religious movements were a prime vehicle for social and political rebellion: equity and justice were stipulated universally, and both Christianity and Islam would stress the humility of all before God. The shared worldview protected kingship, but could also turn into its nemesis. Surely other connections were necessary to consolidate the edifice of royal power.

Rites were performed in seclusion or in full popular view, in many different locations: palaces, religious edifices, tombs, on squares, and in the open field. Palatial designs reflected religious worldviews; façades, moreover, conveyed a sense of power and dignity. The court was a fixed institution as well as a meeting point. It brought together elites and stakeholders for various occasions:

7 On strategies of concealment see Anne Walthall, 'Hiding the Shoguns: Secrecy and the Nature of Political Authority in Tokugawa Japan', in: Bernhard Scheid and Mark Teeuwen, eds., The Culture of Secrecy in Japanese Religion (London, 2013) 332-356. 
attending solemnities and feasts in the ritual calendar, partaking in the ruler's bounty, and engaging in political trafficking. Typically, these occasions overlapped. In modern political culture, representation is a major component of legitimacy. Today, power is accepted because we create our own leadership through elections and thus can influence its agenda. A variant of representation worked in courtly settings, particularly in smaller domains. Here, the extended households of princes could integrate major social groups. Lineages, crafts, and regions were 'represented' by their fellows serving at court, permanently enjoying its lavish hospitality, or sojourning there for special occasions. As long as their expectations were not disappointed these groups could identify themselves as stakeholders of the dynastic venture.

Scale was a major limitation. Enlightened philosophes had argued that republics could function effectively only in smaller territories. ${ }^{8}$ In large-scale dynastic polities, likewise, direct forms of representing and partaking were far more difficult. Only the upper crust of regional elites could be drawn to the court: a thin line of intermediaries maintained the links between centre and periphery. In most of the polities examined in this book, intermediary elites stood between the dynastic centre and the provinces. Only rarely could ordinary subjects share in the court's largesse. The inhabitants of the capital and those living along the trajectories of royal excursions stood a fair chance of profiting from princely benefactions, catching coins thrown to the public, benefiting from charity, royal pardon, tax remits, or provisions distributed to assuage acute crisis. Eager crowds could be involved in royal rituals: a recent study estimates that in Restoration England (166o-1688) around 100,00o persons suffering from scrofula made their way to the court to receive the 'royal touch'. ${ }^{9}$ 'Ombudsman' systems, in addition, in theory were available to all. These mechanisms helped rulers to identify and punish wrongdoers among their agents and at the same time underpinned their reputation as just princes. It is difficult to gauge how frequently subjects actually used these means: petitioning in various forms was accepted in all domains, but complaining directly to the prince in person might demand long travel and was not without risks. Surely the populace as a whole was not as a rule involved in the distribution of the greater court benefits: these were reserved for higher echelons.

8 Most outspokenly perhaps by Jean-Jacques Rousseau, 'Vice Radical', Oeuvres Politiques de J.J. Rousseau, IV, Considérations sur le Gouvernement de Pologne (Paris, 1821) 47-50.

9 Stephen Brogan, The Royal Touch in Early Modern England. Politics, Medicine and Sin (Woodbridge, 2015); see a similar stress on 'bottom up' demand in Neil Murphy, Ceremonial Entries, Municipal Liberties and the Negotiation of Power in Valois France, 1328-1589 (Leiden and Boston, 2016). 
Redistribution took many forms: eating at the king's table, holding office at court, receiving a robe of honour, proudly bearing a court rank, dignity, or office in the provinces, obtaining justice, acquiring wealth. A continuum of forms of exchange and redistribution connects the African village chief entitled to hospitality at the court of his king to the magistrate undergoing highly elaborate forms of evaluation in Late Imperial China. Kings across the globe sensed that they could rule effectively only if they personally controlled the distribution of benefits. This attracted to the court officeholders eager for promotion as well as novices keen to enter the cursus honorum. The presence of contending candidates made it possible to snub the unduly ambitious and elevate loyal servants. At larger courts, no single person could hope to control the machinery of appointments; lesser offices and ranks were distributed without ever reaching the king's desk. For the greatest rewards, however, the ruler would decide - and this put a premium on access. ${ }^{10}$ The ability to frequently and easily communicate with the prince was a key asset: it allowed domestics, advisors, and spouses or concubines to become major forces at court. The perception that these proximates were close to the king's ear persuaded others to ask for their intervention. Brokerage extended the impact of redistribution to regions distant from the court.

Appointments in the elite hierarchies attached to government were the core only of a machinery that involved other spheres of exchange. The presence of numerous women at polygynous courts can be understood in this way. Often, the girls brought together in the harem represented a connection to certain social groups or families; at the same time, rulers could pass on concubines or wives to their followers. The Mughal Padishahs included Rajput princesses in their harem and gave away their concubines or spouses to loyal friends. ${ }^{11}$ Elsewhere, too, harem women could be used to cement alliances with elites; moreover, dynastic princesses were often wedded to trusted allies. Women were essential for many types of alliances. Ottoman sultans wedded their daughters to leading viziers and pashas. In Europe the process of creating cohesion through the exchange of women could not take shape in the same way. The inflating numbers of male honorary officers at most early modern European courts can be understood as a substitute for the huge numbers of women creating ties with local elites in polygynous settings. Monogamous dynastic marriage created external alliances among a closely knit network of

10 See recently Dries Raeymaekers, Sebastiaan Derks. ed., The Key to Power? The Culture of Access in Princely Courts, 1400-1750 (Leiden and Boston, 2016).

11 See an earlier statement on this by Buckler, M.N. Pearson, ed., Legitimacy and Symbols: The South Asian Writings of F.W. Buckler (Ann Arbor, 1985). 
European ruling houses. The ruler's protection over unmarried young ladies at court, in addition, commonly led to the marriage of these girls with males likewise educated at court. Shifting our view of dynastic power from the male to the female line, a dense network of alliances becomes visible. ${ }^{12}$ Charting these connections helps to make visible the stakeholders of the regime.

Nowhere in Eurasia were women the preferred candidates for paramount power. In Europe queens-regnant can be found with some regularity, particularly in Iberia, Britain, Central Europe, and Russia. Dowagers more often served as regents for their minor sons-even in kingdoms where they could not rule in their own right, such as France. Chinese dowagers served as regents tooalthough under the last two imperial dynasties, they reached this elevated stature only infrequently. ${ }^{13}$ In the early modern age, ruling women can be found in Muslim South-East Asia as well as in Japan; but they remained the exception. ${ }^{14}$ In the greater West and South Asian empires women did not hold supreme power - but they were very present as mothers behind the throne and as sisters or daughters forming alliances. In narratives of kingship Richard van Leeuwen encountered what he calls the 'feminine paradox': women are obviously necessary for the consolidation of dynastic power, yet they are often seen in negative terms, as a threat. Kings and heroes need to survive the challenges of coping with female seduction. A misogynist perspective can be found in many literary traditions around royalty, yet surely there was another, more positive, stereotype: the pious, chaste, loyal, and devoted spouse, who counselled mercy and moderation, stepping in to plead for her subjects. In many cases women at court cultivated the positive stereotype, while moving substantially beyond it in their political activity. ${ }^{15}$ Yet there were clear limitations, and open transgressions were likely to be condemned.

Reigning and ruling, we have seen, cannot always be equated. This holds true not only for the Japanese emperor under Tokugawa tutelage. Often viziers,

12 Michaela Hohkamp, 'Transdynasticism at the Dawn of the Modern Era. Kinship Dynamics among Ruling Families', in: Christopher H. Johnson, et al., eds., Transregional and Transnational Families in Europe and Beyond. Experiences since the Middle Ages (New York and Oxford, 2011) 93-106.

13 Keith McMahon, Celestial Women: Imperial Wives and Concubines in China from Song to Qing (Lanham, 2016) outlines changes per dynasty.

14 See an extended discussion in Jeroen Duindam, Dynasties. A Global History of Power 130o1800 (Cambridge, 2015) 89-127.

15 This appears as one of the conclusions in Kim Ragetli's dissertation: 'Duchess between prince and people. A thematic approach to the lives, influence and actions of the Duchesses of Burgundy (1430-1530)'. 
secretaries, and ministers did the work and took the blame, while sultans, emperors, and kings stayed in the background. Maaike van Berkel shows how the literary legacies created by court scribes, probably the most frequently used sources for the history of rulership, helped to define and defend the prestige of this group. Van Leeuwen stresses the triangular relationship between princes, viziers, and concubines in fictional literature, and the 'composite' character of kingship: this was a joint effort rather than the single-handed performance of one player only. ${ }^{16}$ It is important to separate the omnipotence rhetorically attributed to rulers from the usually more modest powers they exerted in practice. Moreover, we should keep in mind the recurring phenomenon of insecure princes who left matters in the hands of confidants. Kings could wield enormous power at times: founding emperors fighting their way to the throne are an obvious case. However, many other examples can be cited where advisors, at least for a decade or two, were able to dominate their kings and push through decisions. On the whole, the powers of kings were more limited than we tend to imagine. A prime factor in this balance simply was distance. Measures decreed at the centre did not always reach the periphery, and if they did, it proved difficult to enforce and verify implementation. This explains the quintessential role of intermediary elites, which will be discussed at some length below. Even at the centre control was never a given. The groups pressing around their nominal leader were eager to obtain benefits for themselves and for their followers. The most ambitious among them, moreover, wanted to wield power themselves, either as the puppeteer moving the king or as the usurper taking his place. How could kings deal with this persistent challenge?

\section{$5 \quad$ Elites: Functions, Recruitment, Competition}

Kings ruled most effectively when supported by a strong, loyal, and collegial group of advisors, a situation that could never be taken for granted. Many kings found out to their dismay that their rule was possible for quite different reasons: because leading advisors and their followers tended towards competition rather than towards cooperation. They understood that this competition was furthered by the rewards in their hands. Competition generated leeway and choice, as long as the distribution of key benefits and positions did not antago-

16 See also Cumhur Bekar's work on the balance of power emerging between Sultan Mehmed IV and the Köprülü viziers, 'The Rise of the Köprülü family. The Reconfiguration of the Vizierial Power in the Seventeenth Century'. 
nize elites en bloc. This idea, which has been stated implicitly and explicitly by rulers worldwide, could be extended from the even-handed distribution of graces to active manipulation. Rather than rewarding their most able and loyal servants, kings could use this instrument to foment competition. Rule by dividing has traditionally been understood as the preferred weapon in the royal arsenal. ${ }^{17}$ Numerous examples can be culled from advice literature and autobiographical writing by kings, but also from historical practice worldwide. Such cases can be separated into two categories: kings often counterbalanced the power of pushy individuals by promoting their rivals; more ambitiously, they could attempt to do this at the level of 'social engineering' for entire elite groups. Offsetting the power of the overly ambitious must have been common practice. Moving against entire groups and redefining the upper layers of society could be carried out only during severe disturbances. It was usually triggered by a key problem of ruling: the tendency of all loyal servants to turn into vested elites.

Elites serving dynastic rulers can be described in many ways. There is the occupational background: domestics, administrators, soldiers, priests. Domestics did not on the whole rise to formal social prominence. In most polygynous settings eunuchs served in the inner court. They could rise to great wealth and power yet their status remained tainted-more strongly so in East Asia than in West Asia. In Europe leading nobles headed domestic staffs as a token of their hierarchical proximity to the ruler-yet their offices in the army and in government defined their identity as much as their honorary domestic service. Warrior elites were prominent in Europe, West and South Asia, yet in the Sinosphere, they rarely matched the prestige of literati in imperial service. Typically, religious elites served their divine overlord and formed part of a separate religious hierarchy: they were rarely integrated wholly and unconditionally into the secular ruler's service.

Pen and sword appear as the two most widespread categories of state servants, yet people of the pen often remained closely tied to people of the book. In the European case clerics, long holding a near-monopoly in literate skills, dominated high administrative office into the sixteenth century. Until the French Revolution, however, Catholic priests were never only or even primarily servants of the state. In the Islamic setting, the 'ulama' as a group remained apart from the state, yet they held many judicial and administrative offices under the authority of the prince. While Confucian literati magistrates in China did not have a fixed religious orientation or status, they were involved in the per-

17 See the classic form of this view in Elias, Court Society. 
formance of local variants of the great imperial rites. Moreover, they certainly occupied high moral ground and at times hazarded to admonish the emperor in person. Maaike van Berkel shows that people of the pen across Eurasia cultivated a powerful identity, stressing their specific literary capabilities and their role as moral leaders. They viewed the activities of paymasters and accountants as below their station and maintained a certain distance from military elites. Compared to the long-established traditions of highly literate administrators in the Islamicate world and the Sinosphere, European state servants arrived late.

The form of the military varied from small bodies of guards and retainers to huge field armies, up to the Chinggisid version of the 'people-in-arms' as described by Jos Gommans. Among nomadic peoples military elites would also perform executive administrative tasks; the emergence of specialized administrative agents can be seen as a step in the development towards sedentary consolidated polities. People of the sword cherished an identity based on valour and loyalty. It never wholly overlapped with the outspoken literary-cultural style of the pen, but intermediate forms can be found in many places. Paradoxically, as van Berkel and Gommans point out, the identity of men of the sword was captured in writing by men of the pen. A rapprochement in the ideals of literary refinement (wen) and military prowess $(w u)$ recurs in Chinese dynastic history ${ }^{18}$ Similar combinations of valour and refinement can be seen among other elites orbiting the dynastic court: Ottoman pashas and viziers, European nobles, and Mughal mansabdars.

This mixing of ideals raises the question of priority: which groups can be seen as predominant? No simple lasting regional typology can be given here. Nevertheless, it is clear that literary accomplishment and high civil office together served as the acme in Late Imperial China. This priority was repeatedly challenged during phases of dynastic turmoil, and it was altered when the Qing conquest elite introduced a martial hereditary structure at the heart of the state and in the government of the newly conquered peripheries. Even under the Qing, however, literary skills retained immense importance and supreme prestige: a fact underlined by the representation of emperors as men of learning. This outspoken dominance of literary elites cannot be found elsewhere. Notwithstanding the stress on Holy Law and the age-old literary traditions of government of the Islamicate world, sultans, shahs, and padishahs granted a prestigious place to leading warriors. Ottoman viziers combined military prowess, literary accomplishments, and patronage of the arts—yet arguably

18 Barend Noordam, 'Military Identity, Empire and Frontier in the Late Ming Dynasty: Qi Jiguang (1528-1588) and His Service on Two Frontiers'. 
their first task was organizing military success. This may have been the common priority throughout West and South Asia: officials defined their identity as experts in writing and emphasized the importance of the pen for the ruler, yet in everyday practice the people of the sword predominated. However, the balance between pen and sword shifted frequently and was never quite resolved. In Europe the clergy ranked as the first estate, but the second estate of the bellatores absorbed many leading positions in the church and predominated in government. Nobles dominated in church and state and they consistently cultivated their connection with the battlefield. The noble estate enjoyed fiscal exemption because they paid taxes in blood: the impôt du sang. Battlefield heroism was the quickest road to noble status, although from the sixteenth century onwards numerous roturiers were ennobled through loyal service and through the purchase of office. European nobility was exceptional because of its marked presence in the church, in the army, and in government.

These elite groups were recruited in various ways. Everywhere the relative importance of descent versus education and talent was hotly debated; everywhere, we can surmise, these categories were present to some extent in the recruitment and selection of military and administrative intermediaries. Still, there are remarkable contrasts here. Europe relied on heredity to a greater extent than did any of the other areas. Old and new nobles produced impressive genealogies to underscore their status: the 'age' of a house was accepted as an important status marker. In many realms, only nobles of 'ancient race' could hope to be admitted to the honours of the court, and they formed an elite pool of recruitment for army command. Conversely, the leading elite of the classic Ottoman age cultivated its 'slave' background; many among them had in fact been recruited through devshirme. Slave-soldiers had a long pedigree in Islamic history, but the Ottomans were remarkable in using the mechanism to fill all major government posts except those traditionally held by 'ulama'. Since the Song, examinations had been an important tool to recruit civil magistrates in China. From the reintroduction of the exams in late Yuan to their final abolition in the early twentieth century the exams would be the main channel of advancement into officialdom. There were exams for the military, but they never achieved either the near-monopoly or the social prestige of the civil exams, and hereditary status remained important here.

Devotion offered another way to elite status. Partly as a result of the increasing impact of Turkic migrants and settlers, Islamic courts could develop a strong mystical tradition, which invigorated already existing notions of royal leadership and charisma deriving primarily from the pre-Islamic Persian tradi- 
tion. ${ }^{19}$ Re-enacting the life of an increasingly romanticized nomadic warband, post-nomadic Turko-Islamic dynasties across West and South Asia built new forms of cohesion through the rhetoric and ritual of personal love and devotion, often to the utter dismay of the wardens of orthodoxy. This Sufi ingredient of 'asabiyya — exemplified most of all by the Safavid model — gave Islamic rulers magical leverage over their followers that went beyond European and East Asian notions of royal charisma. This Islamic Sonderweg of Sufism and service through devotion could not survive the age of religious reform that started at the very end of our period.

Beyond the regionally differentiated interplay of function, priority status, and forms of recruitment another process emerges: the powerful tendency of all elites to pass on wealth and status to their kin and create lasting family networks with their clients. Maaike van Berkel points to the relevance of family relations and clientage even among 'bureaucratic' families professing the priority of education and meritocracy. Patrimonial tendencies complicated all delegation of power: distance and time inevitably turned agents of central power into self-serving powerholders. An endless series of means can be listed through which rulers tried to prevent or delay this process. Chinese 'laws of avoidance' prohibited the assignment of magistrates to their regions of origin as well as the nomination of family members in their retinue or in contiguous areas. Intricate systems of evaluation and reassignment stood at the basis of a carrousel of leading magistrates in Mughal, Ottoman, and Chinese administration - not so different from the introduction of the French intendants in France under Richelieu, often seen as the harbinger of the modern state. Special travelling agents were instituted to check on local officeholders in many places-a listing would include Carolingian missi dominici, Abbasid travelling officials and their successors in later West Asian polities, as well as Chinese censors.

Processes of centralization and devolution can be found in most empires. The classic age of Ottoman power coexisted with the rise to power of devshirme recruits in government and the reduction of former semi-tribal Ghazi frontier lords. Yet military challenges around 1600 and again towards the end of the seventeenth century made it necessary to enlist the support of locals to raise funds and troops. These measures, intended to solve acute fiscal-military crises, created new regional elites and in the long run furthered a process of decentralization. Similar processes can be seen in Central and South Asia. Akbar

19 See in particular Azfar Moin, The Millennial Sovereign. Sacred Kingship and Sainthood in Islam (New York, 2012). 
had harnessed the powers of his multiple and diverse followers through the mansabdar system; yet from the late seventeenth century onwards, Aurangzeb and his successors saw their central powers wane and witnessed the rise of provincial grandees. The Safavids rose to power through Shah Ismail's messianic leadership and the devout support of the new Qizilbash elites. These semi-tribal leaders soon became restive; under 'Abbas I they were reduced in power and counterbalanced by an Ottoman-style slave elite. Nevertheless, the Safavid realm underwent a rapid decentralizing process in the late seventeenth century. Qing China proved remarkably resilient, but in the early decades of the nineteenth century, the combined pressure of internal dissension and the external threat of Western hegemonic powers strained it to the utmost. One of the explanations of Qing success, the steadfast loyalty of the hereditary military banners, a small minority among the numerous Han Chinese, can at the same time be ranked among the causes of the rebellions proliferating from the late eighteenth century onwards. The privileged status of the small conquest elite angered the Han Chinese population. Anti-Manchu sentiments formed a combustible concoction with Ming loyalism, social discontent, and religious sectarianism. The Qing banners, consequently, lacked an opportunity that was present in most other cases: it was more difficult for them to 'turn local', using local ties to improve their position and loosen their ties with the central establishment.

Jos Gommans lists the need to prevent 'gentrification' as the primary purpose of the artificial tribal structure of the Chinggisid warband; and he views the Qing banners as a conscious revival of this practice. Regionalization and patrimonialism were present everywhere, but in different measure. Following Victor Lieberman, Gommans suggests that the waves of conquest originating in the Central Asian steppe created an 'exposed zone' where populations were frequently uprooted and realigned in the warband structure: this prevented the development of a hereditary landed elite. In the 'protected zone' hereditary landed elites survived more easily and hence held a stronger bargaining position vis-à-vis central authorities. Europe and South-East Asia would be the prime examples here. Contrary to traditional views of European state formation, the strengthening of the state coincided with the consolidation of noble privilege and power. ${ }^{20}$

This returns us to the question opening this section: divide et impera. Function, status, and forms of recruitment gave rise to structural tensions among

20 See e.g. Hillay Zmora, Monarchy, Aristocracy and the State in Europe 1300-1800 (London, 2000). 
groups around the ruler. Inner and outer, to some extent overlapping with domestic and administrative functions, but with an added gender difference, can be added to the list. Jeroen Duindam subsumes forms of conflict at court under three hierarchies of respectively rank, decision-making, and access. No single group dominated in all hierarchies, and sharp status dissonance existed, primarily between 'lowly' inner court confidants and respected outer court dignitaries. The functional divides between pen and sword and the partly overlapping divide in palace topography and social status caused lasting tensions that would repeatedly give rise to collective clashes. More often, however, competitors in each of the hierarchies sought alliances in the other hierarchies. Leading literati vied for the same rewards and could benefit from inner-court support. Confidants in the inner court would have difficulty sharing the ruler's trust with their peers and likewise were enticed to align with outer-court administrators or soldiers. Perhaps the most common form of competition was based on family networks, bringing together relatives, affines, and clients of various kinds. Where we have detailed information, these networks appear as remarkably lasting.

Rulers could and would step in actively to support loyal friends and snub the haughty. Openly choosing sides in a conflict, however, represented a grave risk. Favouring one side through unbalanced distribution of honours would antagonize the other, forcing them to seek alternatives. The disenfranchised could, for example, turn to the heir apparent or to other dynastic rivals, betting on future rewards while souring the atmosphere between father and son or between the ruler and his leading relatives. Kings were hesitant to stir up conflict: their task was maintaining order. Conflict was rife without the intervention of kings, and more often than not it persisted against their will and best interests. Moreover, once kings crossed the critical line and actively encouraged antagonism, they often found out to their dismay that it could no longer be controlled. Sometimes they shifted this burden onto their successors. In eighteenth-century Korea, the tragic conflict between King Yongjo and his heir-apparent Sado was in part the legacy of their predecessors' manipulation of faction at court.

The setup around the ruler has been likened to a circulation system, with the ruler pushing his confidants upward and outward, using them as trusted agents. ${ }^{21}$ Once they moved to higher rank and into the periphery, they gradually lost their proximity but found themselves rewarded by higher and more

21 See the short and lucid introduction by Werner Paravicini, 'Der Fall des Günstlings. Hofparteien in Europa vom 13. bis zum 17. Jahrhundert', in: Jan Hirschbiegel and Werner Paravicini, eds., Der Fall des Günstlings: Hofparteien in Europa vom 13. bis zum 17.Jahrhundert: 
independent status. Rulers in all regions employed groups they considered as particularly dependent and dependable against overbearing elites. Celibacy, in addition to literacy, turned European clergymen into preferred agents of royalty: patrimonial goals were not out of reach for them, but more complicated to achieve. The same can be said with greater force about eunuchs. In both cases family networks and adoption made possible long-term patrimonial strategies; and in the case of clergymen illegitimate offspring could play a role. More generally outsiders were chosen as confidants: foreigners, exiles, social climbers. Mamluks employed numerous Christians in their administration; the Yuan dynasty cultivated Central Asians at court and in officea pattern repeated in a more systematic form by the Qing. Outsiders could not fall back easily on local networks of high status friends and loyal clients: for the ruler, this absence of local affiliations was an advantage. En masse recruitment of slaves for leading office, as was practised by the Ottomans, extends the individual process to a collective level. Only the Chinese examinations, however, effectively prevented heredity at the level of individuals in office and made it possible - in theory but to some extent also in practicefor talented outsiders to reach high rank. The formation of wealthy literate gentry lineages, able to maintain themselves through repeated exam success, did not reduce the potential of the examinations to render legitimate the power of the emperor and his magistrates. At the other end of the spectrum, European elites unabashedly pointed to their pedigree and claimed heredity in office more often than did their Eurasian compeers elsewhere. They, in fact, behaved like miniature dynasties, mirroring at a lesser level the strategies and legitimations of European rulers. The wider social resonance of noble dynastic ideology was peculiar to Europe and Japan. ${ }^{22}$ Elsewhere, slaves, examination graduates, disciples, and dependents were repeatedly successful in obtaining semi-hereditary status, yet the representation of these powerholders was rarely as outspokenly dynastic as among European noble houses.

8. Symposium der Residenzen-Kommission der Akademie der Wissenschaften zu Göttingen (Sigmaringen, 2004) 13-21.

22 See an early statement in this direction by Fernand Braudel, 'A propos des origines sociales du capitalisme', in: La dynamique du capitalisme (Paris, 1985) 75-79; I thank Peer Vries for pointing out this passage. 
The preceding paragraphs may seem to confirm a common perception of pre-modern history in general and the 'Orient' in particular: a maelstrom of events that in the end left everything unchanged. Dynasties came and went, yet the common pattern of rule subsisted in roughly the same form. Incumbents changed, battling courtiers were replaced, yet throne, altar, and elites persisted. There is some truth in this: a repetition of patterns is unmistakably present, which makes it easy to understand the ubiquity of cyclical models among premodern political thinkers.

However, radically different views are possible. Karl Jaspers suggested an 'Achsenzeit', a breakthrough-age profoundly changing philosophy on the Eurasian continent between the eighth and third centuries вСЕ. ${ }^{23}$ Victor Lieberman postulated a shared tendency towards centralization and integration in major polities across the Eurasian continent neatly coinciding with the time span of this book. ${ }^{24}$ This convergence can be extended to include the 'crisis of the seventeenth century' recently redefined in global terms by Geoffrey Parker. ${ }^{25}$ In this sense, the preceding chapters fit well Lieberman's thesis. The major polities emerging from the later Middle Ages onwards in each of the regions studied could, with some justification, see themselves as perfecting the achievements of their predecessors. Chinese dynasties considered the reasons behind their predecessors' downfall. Each dynasty came with a programme intended to prevent certain conspicuous shortcomings, and these intentions could make a difference. The sequence of the Ming and Qing dynasties can be seen as a gradual build-up of administrative capability and political acumen. ${ }^{26}$ The Tokugawa shoguns had reason to look upon their government as an enhanced version of previous models of rule in Japan. Likewise, the great empires of West and South Asia could with some justice view their achieve-

\footnotetext{
23 Karl Jaspers, Vom Ursprung und Ziel der Geschichte (Munich, 1983 [1949]).

24 Victor Lieberman, Strange Parallels: Southeast Asia in Global Context, c. 800-1830 (Cambridge, 2003, 2010).

25 Geoffrey Parker, Global Crisis: War, Climate Change and Catastrophe in the Seventeenth Century (New Haven, 2013).

26 See, for instance, McMahon, Celestial Women, on the adaptions consciously introduced by the Ming and Qing; Evelyn S. Rawski, The Last Emperors: A Social History of Qing Imperial Institutions (Berkeley and London, 1998) with a perhaps slightly overstated image of the lessons learnt and put in practice by the Qing; and R. Kent Guy, Qing Governors and Their Provinces: The Evolution of Territorial Administration in China, 1644-1796 (Seattle, 2010) with a careful rendering of changes in the structures of government.
} 
ments as surpassing the efforts of their dynastic predecessors, in terms of cultural brilliance as well as political centralization. Europe, too, fits the pattern: changes here were particularly rapid because they started at lower levels and were fostered by permanent competition - with the Ottomans as well as among European contestants. However, profound change everywhere mixed easily with veneration for an idealized past golden age. Arguably, moreover, it left untouched the basic outlines of society. Perhaps this can be stated only with hindsight, on the basis of the turbulent and ongoing process of transformation in the centuries following $175^{\circ}$.

This comparative research effort consciously left aside the questions raised by the rise of Europe. Yet does it tell us anything about Europe's specificity? First of all, our focus on prince, pen and sword points to divergences in all parts of Eurasia that are not usually integrated into the story of European ascendancy. In the preceding pages, the regional variants of elite recruitment have been discussed. Surely the Chinese civil service examinations can be seen as a Sonderweg: they appear as the single premodern formula structurally reducing the inbuilt erosion of elite loyalty, while at the same time underpinning imperial legitimacy and the social pre-eminence of the literati elite. ${ }^{27}$ The formula was geared to produce stability and order rather than economic innovation or global hegemony - but it did not hinder the remarkable military, demographic, and economic expansion of Qing China. Qing military success, however, may in part be explained by the adoption of the semi-tribal banner elites. The banners direct us to Jos Gommans, who points to a Sonderweg at the other extreme of the spectrum: the Chinggisid warband. This powerful model allowed rapid conquest and mobility, but by definition lost its character during consolidation and sedentarisation. Gommans adds that, particularly in the empires proximate to the Mongol example, elite loyalty was temporarily reinvigorated by the Sufi rhetoric of personal devotion to the ruler as spiritual leader.

How does Europe fit within these regionally diverging examples of ruler-elite relations? Undoubtedly the most conspicuous divergence here is the norm of monogamous marriage: it cannot be found in other dynastic settings. Monogamy had a series of consequences for palace organization and layout, for the format of royal families and succession strife, and for the nature of dynastic alliances. West, South and East Asia, all subscribing to polygynous reproduction, show great variety in each of these respects, yet Europe stands apart with its web of dynastic alliances and succession rights. However, this cannot be

27 See the eloquent statement by Benjamin Elman, 'Political, Social, and Cultural Reproduction via Civil Service Examinations in Late Imperial China', The Journal of Asian Studies 50, no. 1 (1991) 7-28 and other works by the same author cited by Maaike van Berkel. 
read as a sign of consolidation or stability. A critic of intrigue and ambition, Erasmus expressly warned against the tendency of princes to marry prestigious brides from rivalling sovereign houses. He argued this would exacerbate warfare:

For while kingdom is linked with kingdom by marriage contracts, whenever one party takes offence, he appeals to his rights of relationship to draw others in, and so on the slightest offence Christendom moves to arms, and the displeasure of a single man is assuaged with a deluge of Christian blood. ${ }^{28}$

Erasmus urged princes to marry among the nobles in their realm, but his injunctions were not taken seriously. Succession conflict, mostly internal though at times with wider regional repercussions in Asian empires, took the form of warfare between kingdoms in Europe. Warfare among the smallerscale European contestants was endemic: protracted periods of peace were exceptional. Succession could serve to legitimize straightforward conquest, yet it did imply a certain respect for the customs and expectations of the lands obtained, particularly for locals who had supported the conqueror's claim. While these ongoing wars were destructive and expensive, succession conflict tended to leave intact corporate rights and exemptions: privileged groups in society retained their positions. This contrasts with the devastating waves of expansion moving outward from the nomadic heartlands of Eurasia to the 'exposed zones' where major sedentary empires arose. Jos Gommans outlines the flux and social mobility characterizing the Chinggisid warband and the emulations of the Steppe model of military mobilization. The Habsburg-Jochid comparison proposed by Liesbeth Geevers and Marie Favereau highlights the fact that Habsburgs, moving from place to place as a consequence of dynastic marriage and succession, conformed to the 'laws of the land', a notion that cannot be found in the Jochid context.

Monogamous marriage, presented by Georges Duby as the victory of prêtres over guerriers, points to the relative strength of clergy and church in Europe. ${ }^{29}$ This, indeed, was unmatched: the position of religious intermediary elites appears as one of the main differences between Europe, West-South Asia, and

28 Desiderius Erasmus, 'On the Marriage Alliances of Princes', Percy Society Corbett, ed., Erasmus' Institutio Principis Christiani (London, 1921) 50-52.

29 See Georges Duby, Le chevalier, la femme et le prêtre. Le marriage dans la France féodale (Paris 1981), particularly 27-59 on the clashing views of priests and warriors, and 201-219 on the implications for the royal house. 
East Asia. This theme requires more study. Can it be related to the norm of succession through monogamous reproduction, and to that other outspoken characteristic of Europe, heredity and the persistence of noble power? Indeed, in Europe, the strength, resilience, and vociferous defence of hereditary privileges strike the eye. The language of local and corporate rights, a traditional elite response to encroaching state power, was rephrased in the eighteenth century by Montesquieu and his adherents. Montesquieu explicitly presented the accumulation of freedoms as a prime safeguard against the rise of despotism: the privilege of elites, for him, stood at the heart of the ideal of political liberty. Yet how can we match this view of forces counterbalancing royal power with the undeniable strengthening of European states, another key element of the narrative of European modernization? It is difficult to see monogamous marriage, a strong clergy and church, and a powerful stress on heredity as harbingers of modernity and breakthrough.

Military and commercial competition and innovation have been cited among the causes of the European breakthrough because they forced as well as enabled the contestants to improve their fiscal and administrative techniques. Maaike van Berkel shows that specialized administrators emerged late in Europe; yet the latecomer rapidly made up arrears and soon overtook the others. Arguably, the leading states of Europe surpassed the administrative capacities of older Eurasian traditions in the course of the seventeenth and early eighteenth centuries. The limited scale of European kingdoms made increased state control more feasible. Moreover, credit systems based on mercantile wealth were added quickly to the relatively static revenue generated by taxation. ${ }^{30}$ Generating income from society could work in the short term through forced loans and confiscations or by negotiated loans penniless princes often failed to repay, a common experience for banking houses in Europe. In the end tapping private wealth successfully and lastingly demanded a trustworthy state that honoured its obligations. Most great empires relied first and foremost on land taxes and labour services, their political elites cultivated a more distanced attitude vis-à-vis traders, and income generated through mercantile wealth remained limited.

The 'European sea nomads' found their way to distant shores and continued their battles there-with their Old World rivals as well as with locals. ${ }^{31}$ The

30 David Stasavage, States of Credit: Size, Power, and the Development of European Polities (Princeton, 2011) focuses on the small scale of states, the presence of merchant elites and the connections between political representation and credit.

31 Victor Lieberman, 'Protected Rimlands and Exposed Zones: Reconfiguring Premodern Eurasia', Comparative Studies in Society and History 5o, no. 3 (2008) 692-723, 721. 
unrelenting pressures of war continuously changed the rules of the gamewith successive rounds of military, financial, and administrative change in the later Middle Ages, the early seventeenth century, around the turn of that century, and again from the 1740 onwards..$^{32}$ Every round of military-fiscal escalation tested the compact between rulers and their elites, and in the 1780 os a critical threshold was passed. ${ }^{33}$ In the following decades of revolution and war, Britain resisted the Napoleonic challenge and fortified its global dominance. Conversely, in 1711, after consolidating the gains of Qing China, the Kangxi Emperor decided to freeze the head tax. Kangxi's decision can be explained by his zeal to be seen as a sage ruler, preventing the exploitation of the people through unnecessary expenditure for magnificence or warfare-princely penchants that were seen as causes for a downturn in the dynastic cycle. His reticence did not weaken China. Only in the late Qianlong years, after a century of stunning growth in all respects, did Qing leadership start to show signs of administrative fatigue, with corruption rampant and rebellions proliferating. By the mid-nineteenth century the increasingly bullying presence of Europeans along the East Asian seaboard mercilessly exposed China's unexpected vulnerability. ${ }^{34}$ Whether or not Kangxi's choice put 'all under heaven' at risk, the more important observation is that it would have been unthinkable for any of the major players in Europe. While individual states could reach a level of satisfaction and might prefer reticent policies, assertive contenders would force them back into the game - or push them out altogether.

The overt global hegemony of Europe occurred late and suddenly, as the consequence of two profoundly different breakthroughs and a devastating war. This was the consequence of innumerable long-term factors and contingencies.

32 See a careful recent view focusing on the period of breakhtrough, Peer Vries, State, Economy and the Great Divergence: Great Britain and China, 1680s-1850s (London and New York, 2015); Philip T. Hoffman, Why Did Europe Conquer the World? (Princeton, 2015) postulates a longer-term 'tournament model' of competing European small-scale territories in the absence of any hegemonic power. The novelty cannot be found in the formula itself, but in the systemic, and finally mathematical form given to it. See Martin Van Creveld, The Rise and Decline of the State (Cambridge, 1999) summarizing similar factors (multipolarity, the failure of 'empire', permanent military competition).

33 See Lars Behrisch, Die Berechnung der Glückseligkeit. Statistik und Politik in Deutschland und Frankreich im späten ancien régime (Ostfildern, 2016) for a careful assessment and explanation for the rising force of statistical fact-finding and planning, a development that took shape mostly after the Seven Years' War.

34 On the gradual reorientation of Qing policies during this critical phase, see Matthew Mosca, From Frontier Policy to Foreign Policy. The Question of India and the Transformation of Geopolitics in Qing China (Stanford, 2013). 
Others have enumerated and evaluated reasons why the situation in Europe turned out to be more conducive to this multifaceted and epochal transformation than conditions elsewhere. ${ }^{35} \mathrm{~A}$ single country spearheaded the process. Britain's global hegemony was a consequence of the Industrial Revolution, the military success against Napoleon, and the impulses of the French Revolution. Restoration governments throughout Europe were eager to extinguish the revolutionary flame, yet they happily adopted instruments created by the Revolution to enhance state powers. In the same decades, industrial production revolutionized the economy and gradually changed the basis of warfare.

The availability of military forces and seaborne power, supported by an advanced political and financial capacity, and animated by a mentality that embraced violence as the necessary continuation of policy together formed the basis of European hegemony. Saying that the will and capacity to use organized violence on a large scale was a precondition for establishing European hegemony is stating a tautology. The willingness to use violence, moreover, surely did not set European powers apart from their Asian competitors. Yet the fact that Europe achieved its position through military superiority and a belligerent attitude does not easily fit the view of the West as the harbinger of universal rights and freedoms, as the continent where a more balanced relationship between the state and its stakeholders created public credit as well as political modernity. The rise of European hegemony should be separated analytically from the rise of the European socio-political model. Modernity and liberalism came in the baggage train of armies and navies.

See Vries, State, Economy and the Great Divergence, and other titles mentioned in the introduction to this volume (note 26 , pages 10-11). 